\title{
Silver effect on the biodegradation process of styrene-ethylene/ butylene-styrene based thermoplastic elastomers compounds upon weathering exposure
}

\author{
Tomacheski, D. ${ }^{1,2}$; Pittol, M. ${ }^{2}$; Vier, S. ${ }^{1}$; SimÕes, D.N. ${ }^{2}$; Ribeiro, V.F. ${ }^{1,2}$ \& SAntana, R.M.C. ${ }^{1}$ \\ ${ }^{1}$ Department of Materials Engineering, Laboratory of Polymers - LAPOL, Universidade Federal do Rio Grande do Sul, UFRGS, 9500 \\ Bento Gonçalves Avenue, Postal Code 15010, Porto Alegre 91501-970, Brazil \\ ${ }^{2}$ Softer Brasil Compostos Termoplásticos LTDA, 275 Edgar Hoffmeister Avenue, Campo Bom 93700-000, Brazil
}

Received November 20, 2017; Accept February 16, 2018

\begin{abstract}
The incorporation of antibacterial additives in polymeric materials has become common to reduce the colonization of microorganisms in daily household items. This kind of product can be helpful to prevent diseases, but following the end of its useful lifetime, it might become an environmental problem, causing hazards also to the beneficial soil-borne microbes. This study aims to evaluate the effect of thermoplastic elastomers (TPEs) compounds loaded with silver ions $\left(\mathrm{Ag}^{+}\right.$bentonite, $\mathrm{Ag}^{+} \_$phosphate) and nanoparticles (AgNp_silica) in the soil microbiota. Samples were exposed to weathering for 3, 6,9 and 12 months, and monitored by carbon dioxide $\left(\mathrm{CO}_{2}\right)$ production in the soil for 4 months. Standard sample exposed to weather by 6 , 9 and 12 months showed higher $\mathrm{CO}_{2}$ production than samples unexposed or exposed for 3 months. By contrast, silver-loaded samples had higher $\mathrm{CO}_{2}$ production in samples pre-aged for 3 months, but the values decreased in samples pre-aged for 6, 9 and 12 months. Moreover, soil microbial counts were lower in samples that had lower $\mathrm{CO}_{2}$ production. Though the amount of silver in the soil has been lower than the limit of detection, after intense exposure to weather, the degradation of the polymer may have facilitated the release of silver from the TPE matrix, and on these terms, silver may have caused a harmful effect on soil fungi and bacterial population.
\end{abstract}

Keywords: Microorganisms · Silver · Degradation · Elastomeric matrix.

\section{INTRODUCTION}

The quality of causing the death of microorganisms or suppressing its growth is a desired characteristic in thermoplastic elastomers (TPEs), which can be used in nosocomial environments, food manufacturing facilities, and personal healthcare products. For this purpose, antimicrobial substances such as silver, zinc, and copper can be incorporated into materials to induce biocide qualities (Pittol et al., 2017; Ribeiro et al., 2017). However, concerns exist regarding the degradation of these metal-containing materials after the end of its service life.

Polymers possess structures resistant to biodegradation, being less susceptible to microbial attack due to their high molecular weight, hydrophobicity, the presence of antioxidants, and lack of biodegradable functional groups such as oxygen and nitrogen (Corti et al., 2010; Russel et al., 2011). Though the plasticizers used in TPE formulations can support microbial growth (Lugauskas et al., 2003), a structure composed solely of carbon and hydrogen make polymers resistant to biodegradation (Zheng et al., 2005). In spite of that, physical or chemical modification resulting from chemical hydrolysis, thermal or photodegradation cause a breakdown of the polymer chains and molecular weight reduction, rendering the polymer more susceptible to the action of living organisms (Bonhomme et al., 2003; Fontanella et al., 2013; Roé-Sosa et al., 2015; Portillo et al., 2016).

*Corresponding author: Daiane Tomacheski; e-mail: daitomacheski@gmail.com 
During biodeterioration, microbial enzymes modify the physical properties of the polymer and enlarging their pores. This process leads to chains cleavage forming low-molecularweight fragments and further assimilation of monomers into living microbial cells (Goldberg, 1995). The activity of soil microorganisms causes substrate oxidation, which can oxidize completely to carbon dioxide $\left(\mathrm{CO}_{2}\right)$. Ultimately, the quantity of carbon released in the form of $\mathrm{CO}_{2}$ indicates assimilation of polymeric material by microorganisms (Gonçalves \& Franchetti, 2015).

The influence of silver in biodegradation process have been discussed in cellulose fibers and polyurethane materials (Klemenčič et al., 2010; Tomšič et al., 2011; Oprea et al., 2017). However, few studies report the impact of materials containing metal in the soil microbiota at the end of their lifecycle (Bao et al., 2016; Samarajeewa et al., 2017; McGee et al., 2017). In this context, investigations addressing the impact of metal ions and nanoparticles on the soil microbial populations are required.

A previous study by this research group showed that the presence of silver in the compound affects its biodegradation (Tomacheski et al., 2017a). The current research attempted to investigate whether the release of silver ions and nanoparticles occurs from the polymer to the environment and whether the metal presence affects the abundance of soil microbes. In order to achieve this aim, TPE samples were exposed to weathering for 3, 6, 9 and 12 months followed by measuring the carbon mineralized from each treatment after 4 months under soil incubation. Besides the respirometric analyses, the soil microbial abundance and the silver content was quantified.

\section{MATERIAL AND METHODS}

\section{Test Materials}

The particles tested were bentonite organomodified with silver (referred to here as $\mathrm{Ag}^{+}$bentonite), silver ions supported in phosphate glass (referred to here as $\mathrm{Ag}^{+}$. phosphate) and nanosilver adsorbed on fumed silica (referred to here as $\mathrm{AgNp}$ _silica). The particles were dispersed respectively into the polymer matrices in mass proportions of $2.0 \%, 0.3 \%$ and $0.05 \%$ according to the additives suppliers. The additives were loaded into a TPE formulation compounded by styreneethylene/butylene-styrene copolymer (SEBS, $32 \%$ styrene, ethylene/butylene 32/68, linear, Mw 214.8 Da) polypropylene homopolymer (PP), white mineral oil (64\% paraffinic and 36 $\%$ naphthenic), in a weight ratio of 30/20/50 respectively. The antioxidant was added to the formulation at the concentration of $0.1 \%$ to prevent thermal degradation during processing. A compound with no antimicrobial additive (Standard sample) was also tested.

More information about the additive used can be found at Tomacheski et al., 2017b. The preparation of TPE compounds were described in a previous study (Tomacheski et al., 2017a).

\section{Polymer degradation studies}

The biodegradability of SEBS-PP compounds was determined by measuring the carbon dioxide $\left(\mathrm{CO}_{2}\right)$ production. The samples were exposed to weathering for 12 months (from August 2015 to August 2016), under real climatic conditions in accordance with ASTM 1435. Samples were collected every 3 months and were buried in the soil during 4 months for performing respirometric tests. Soil used in the respirometric tests was Organosol. The method used for the respirometric experiment was based on parameters reported by Montagna et al. (2013) and Catto et al. (2017) using a biometer flask adapted according to ASTM D 5338 and ASTM D 5988. The results were obtained by using measured carbon dioxide production rates from TPE samples, blank soil and cellulose card sample (positive control) during the incubation time. More information on the methodology are available in Tomacheski et al., 2017a.

\section{Soil characterization}

The soil samples from the respirometric test, in which TPE samples exposed to weather for 12 months were buried during 4 months were used to quantify silver and microorganisms.

For silver quantification, the soil sample $(25 \mathrm{~g})$ was acid digested according to EPA 3050B and the silver was quantified by Inductively Coupled Plasma Optical Emission Spectrometry (ICP-OES, Thermo Scientific iCAP 6300 Model).

The soil $\mathrm{pH}$ was measured using the potentiometric method in a 1:10 soil-water dilution ratios.

\section{Enumeration of soil microorganisms}

For the enumeration of microorganisms, $25 \mathrm{~g}$ of soil sample was suspended in $225 \mathrm{~mL}$ peptone salt solution $(0.1 \%)$ and homogenized in Stomacher for $60 \mathrm{~s}\left(10^{-1}\right.$ dilution). For the enumeration of mesophilic aerobic microorganisms, $1 \mathrm{~mL}$ $\left(10^{-4}\right)$ of the suspension was placed in sterile Petri dishes and molten Plate Count Agar (Oxoid) was added to these plates and incubated for $48 \mathrm{~h}$ at $36 \pm 1{ }^{\circ} \mathrm{C}$. For yeasts and fungi isolation, the dilution $\left(10^{-4}\right)$ was placed in Potato Dextrose Agar (MERCK) for 7 days at $25 \pm 1{ }^{\circ} \mathrm{C}$.

\section{RESULTS AND DISCUSSION}

In Figure 1 is presented the carbon dioxide $\left(\mathrm{CO}_{2}\right)$ production from TPE samples monitored by respirometric assay during 120 days (4 months). The amount of $\mathrm{CO}_{2}$ from flasks containing the standard sample exposed to weather by 6,9 and 12 months was higher than the $\mathrm{CO}_{2}$ from unexposed samples or that one exposed for 3 months (Figure 1a). Considering that abiotic degradation increases the mineralization process, these results are in agreement with the literature. Even at a slow oxidation rate, some chains of the polymer can be fragmented and become susceptible to access of the microorganisms (Corti et al., 2010). In a previous study, after 9 months of SEBS- 

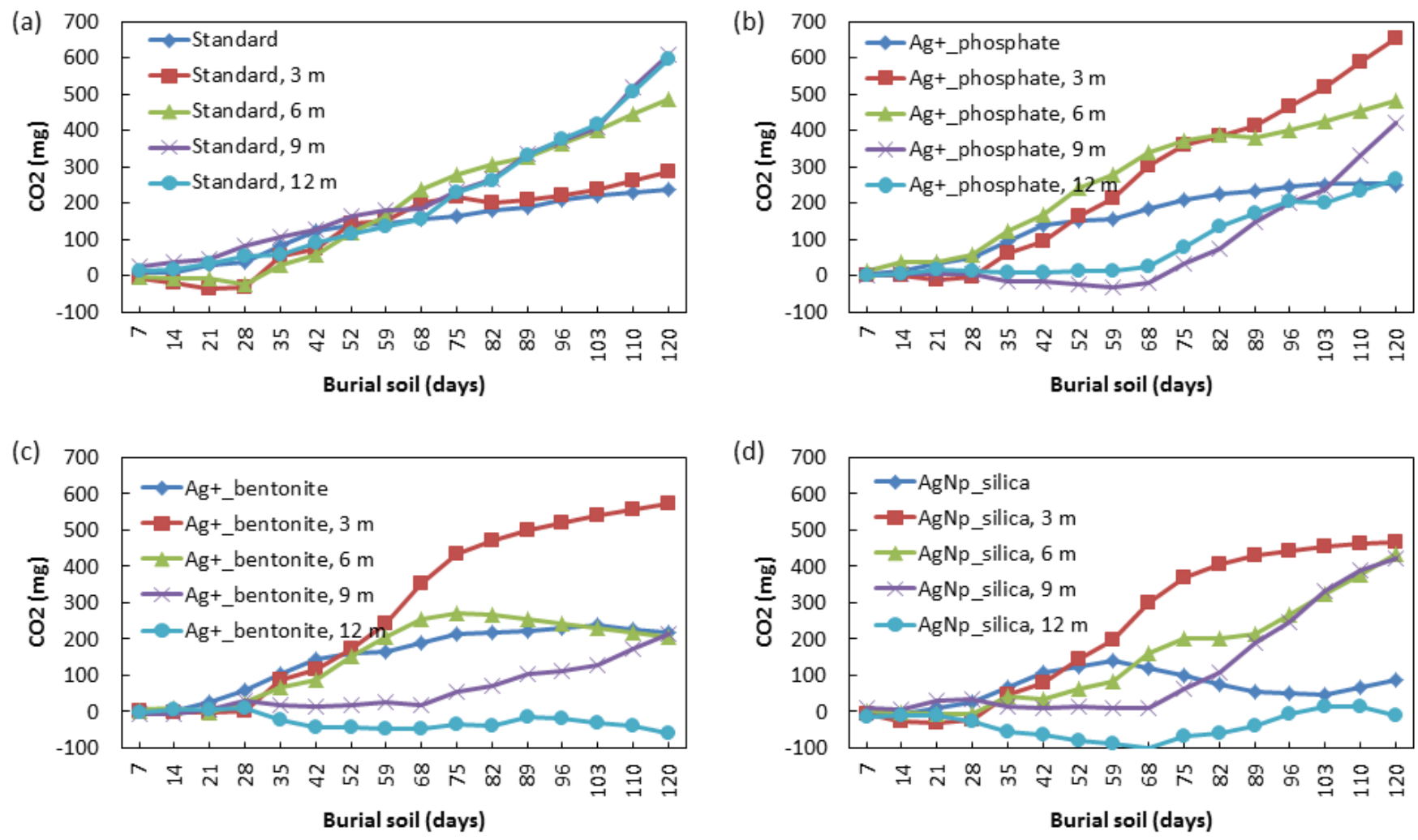

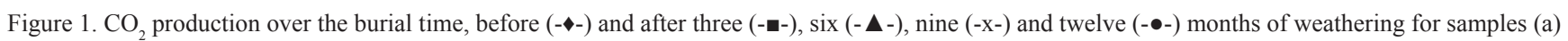
standard, (b) $\mathrm{Ag}+$ _phosphate, (c) $\mathrm{Ag}_{+} \_$bentonite and (c) $\mathrm{AgNp} \_$silica.

TPE exposure to weathering, the polymer degradation was confirmed with the reduction of tensile properties, variation of crystallinity of material and surface modification of polymer with the appearance of oxidation bands verified by infrared spectroscopy (Tomacheski et al., 2017a).

By contrast, in the sample loaded with $\mathrm{Ag}^{+}$phosphate (Figure 1b) $\mathrm{Ag}^{+}$bentonite (Figure 1c) and $\mathrm{AgNp}$ silica (Figure 1d) the $\mathrm{CO}_{2}$ production was elevated in the compounds exposed to weather for 3 months than 6,9 and 12 months.

Near $200 \mathrm{mg}$ of $\mathrm{CO}_{2}$ was generate in $\mathrm{Ag}^{+}$phosphate sample unexposed to weather (Figure 1b). After 3 months of weather exposure, this sample presented an increase in $\mathrm{CO}_{2}$ production starting from the thirty-fifth day of incubation and reaching almost $700 \mathrm{mg}$ of $\mathrm{CO}_{2}$ in day 120 . Following 6,9 and 12 months of weather exposure, the samples reached values of $500 \mathrm{mg}, 400 \mathrm{mg}$, and $200 \mathrm{mg}$, respectively.

In the samples aged for 3 months, the $\mathrm{CO}_{2}$ production was less than $600 \mathrm{mg}$ in $\mathrm{Ag}^{+}$bentonite and less than $500 \mathrm{mg}$ in AgNp_silica. These numbers decreased after 6, 9 and 12 months of weather exposure until achieving values close to or under to zero. This result can be attributed to high abiotic degradation (12 months of weathering) which promoted the release of silver ions and nanoparticles from polymer to the soil, causing an impact on the soil microbial community and diminishing the action of living organisms into the polymer.

The characteristics of the polymer such as crystallinity, molecular weight, functional groups, plasticizers, and additives have relevance in the degradation process (Artham
\& Doble, 2008). In styrene-ethylene/butylene-styrene (SEBS)-based TPE matrices, the metal particles have the tendency to remain in the SEBS/oil phase (Tomacheski et al., 2016). The amorphous part of the polymer matrix is prone to oxidation; whereas the crystalline phase of the polymer is more susceptible to a molecular reorganization, such as chains fragmentation (Corti et al., 2010). Thus, the breaking of polypropylene chains and SEBS/oil permeability can influence the polymer crystallinity and finally favor the release of ions and silver nanoparticles from the polymer to the environment (Tomacheski et al., 2017a).

To verify this hypothesis and assuming that pre-aged samples could present the highest rates of silver release, the average concentration of silver was measured in soils buried with metal-loaded TPE samples for 4 months. However, as can be seen in Table 1 the amount of silver released into the soil were below the limit of detection $\left(<2 \mathrm{mg} \mathrm{g}^{-1}\right)$. The extraction conditions (extraction medium, extraction time and extraction temperature) could influence the extraction levels of silver. Also, it is possible that not all functionalized silver nano-devices will be liberated from the materials in observable amounts (Sussman et al., 2015).

Table 1 presents microbial counts, $\mathrm{pH}$, and silver concentration in the soil exposed to loaded and unloaded TPE. Cellulose material was used as a reference of a material that is certainly degraded (Park \& Kang, 2004). The lower number of bacteria and fungi in control soil can be related to the absence of an available substrate for microbial utilization. 
Table 1. Counts of mesophilic bacteria, fungi and yeasts in the soil (after 4 months).

\begin{tabular}{lcccccc}
\hline & Control soil & Cellulose & Standard & Ag+_phosphate & Ag+_bentonite & AgNp_silica \\
\hline $\begin{array}{l}\text { Mesophilic bacteria } \\
\text { (CFU g }\end{array}$ & $3.80 \times 10^{2}$ & $3.31 \times 10^{3}$ & $1.2 \times 10^{6}$ & $2.40 \times 10^{4}$ & $1.36 \times 10^{3}$ & $2.20 \times 10^{3}$ \\
$\begin{array}{l}\text { Fungi and yeasts } \\
\text { (CFU g }\end{array}$ & $1.00 \times 10^{2}$ & $1.50 \times 10^{6}$ & $5.10 \times 10^{6}$ & $1.36 \times 10^{7}$ & $1.09 \times 10^{4}$ & $2.50 \times 10^{4}$ \\
pH & 5.65 & 5.32 & 5.42 & 5.18 & 5.16 & 5.23 \\
Silver $\left(\mathbf{m g ~ g}^{-1}\right)$ & - & - & - & $<2^{*}$ & $<2^{*}$ & $<2^{*}$ \\
\hline
\end{tabular}

* Equipment detection limit: $2 \mathrm{mg} \mathrm{g}^{-1}$

The soil exposed to standard sample presented the highest bacterial abundance. Among the silver-based compounds, microbial counts were elevated in soil with $\mathrm{Ag}^{+}$phosphate loaded compounds. In the AgNp_silica loaded compounds, soil presented an intermediate number of microbial abundance. The number of mesophilic bacteria, fungi and yeasts were low in soil buried with $\mathrm{Ag}^{+}$bentonite loaded compounds. Fungal counts were higher than bacteria in all metal-loaded samples (Table 1).

Taking into account that phosphate is an essential macronutrient for microbial growth, the high $\mathrm{CO}_{2}$ production rates in the $\mathrm{Ag}^{+}$phosphate experiment could be linked to a lower effect of this additive in soil microorganisms that allowed a better microbial activity on polymer mineralization. The ability to produce metabolites enables the hyphae of the fungus to grow even on microbial-resistant polymers surface (Lugauskas et al., 2003). Since these microbes use oxidation products as a carbon source (Corti et al., 2010) they can cope with metal-stress more effectively than bacteria (Sillen et al., 2015).

The degree of biodeterioration depends on the physical and chemical properties of the polymer, as well of the adhesion capacity of microorganisms, availability of nutrients, $\mathrm{pH}$, temperature, amount of moisture, and oxygen in the system (Tomšič et al., 2011). According to Bao et al., (2016) AgNPs can affect the microbial biomass; however environmental conditions can mitigate the impact of AgNPs on bacterial community structure. Following biodegradation test, the soil $\mathrm{pH}$ of control, cellulose, and standard samples were 5.50, 5.32 and 5.42, respectively and between $5.16-5.23$ in soil with silver-loaded TPE. Given that the $\mathrm{pH}$ of the solution can affect the metabolism and membrane permeability of microorganisms or impact on the oxidation and toxic element release (Schlich $\&$ Hund-Rinke, 2015), it can be proposed that differences in $\mathrm{pH}$ between soils may have changed the availability of toxic elements or the sensitivity of microbes to silver.

Metal and metal oxide present in the environments have been shown to alter microbial growth (Tomšič et al., 2011). In soil ecosystem, Samarajeewa et al., (2017) observed a negatively effect on microbial growth and activity in soil containing AgNPs in the concentration of $49 \mathrm{mg} \mathrm{kg}^{-1}$ and $\mathrm{Ag}$ tolerant bacteria was detected. However, the specie Pelobacter propionicus which has a function in carbon and nitrogen cycles was found to be sensitive to exposure to AgNPs in estuarine sediments (Antizar-Ladislao, 2015). McGee et al., (2017) reported an impact on the ammonia-oxidizing microbes and in the overall microbial communities' structures with the exposure to $50 \mathrm{mg} \mathrm{kg}^{-1}$ of AgNPs.

The metabolic diversity of microbial communities allows transformation of a variety of substrates. However, the multiple factors that occur during this mineralization process hamper the reproduction and control of the experiments in vitro (Lucas et al., 2008). In this study, the sample without silver additive (standard sample) showed higher $\mathrm{CO}_{2}$ production and bacterial abundance. The results documented here does indeed confirm that, in some degree, fungi and bacteria promote the breakdown of polymers and use it as an energy source. However, in the silver-loaded samples, a decrease was observed in microbial counts and $\mathrm{CO}_{2}$ rate. Thus, even without the detection of silver in soil samples, the low $\mathrm{CO}_{2}$ production can be attributed to a silver antimicrobial effect.

\section{CONCLUSIONS}

In the present study, the standard TPE samples (unloaded) presented the highest $\mathrm{CO}_{2}$ emissions and bacterial abundance. In the silver-loaded samples, it was observed that the more degraded the polymer the lower the production of carbon dioxide. The low $\mathrm{CO}_{2}$ production was consistent with low soil microbial counts, giving evidence that even in small amount the silver may have affected soil microbes. Nevertheless, further studies are needed to investigate the biodegradation process of silver-loaded polymer, considering the contribution of others parameters which were not covered by this study such as nutrient concentration in the soil.

\section{ACKNOWLEDGEMENTS}

The authors are grateful to FINEP by the financial support (03.13.0280.00) and Softer Brasil Compostos Termoplásticos LTDA.

\section{REFERENCES}

ANTIZAR-LADISLAO, B., BHATTACHARYA, B.D., CHAUDHURI, S. R., SARKAR, S.K. 2015. Impact of silver nanoparticles on benthic prokaryotes in heavy metalcontaminated estuarine sediments in a tropical environment. Mar Pollut Bull, 99: 104-111. http://dx.doi.org/10.1016/j. 
marpolbul.2015.07.051

ARTHAM, T., DOBLE, M. 2008. Biodegradation of aliphatic and aromatic polycarbonates. Macromol Biosci, 8: 14-24. http:// dx.doi.10.1002/mabi.200700106

ASTM D1435-13 (American Society for Testing and Materials). 2013. Standard Practice for Outdoor Weathering of Plastics, ASTM International, West Conshohocken, PA.

ASTM D5338-15 (American Society for Testing and Materials). 2015. Standard Test Method for Determining Aerobic Biodegradation of Plastic Materials Under Controlled Composting Conditions, Incorporating Thermophilic Temperatures, ASTM International, West Conshohocken, PA.

ASTM D5988-12 (American Society for Testing and Materials). 2012. Standard Test Method for Determining Aerobic Biodegradation of Plastic Materials in Soil, ASTM International, West Conshohocken, PA.

BAO, S., WANG, H., ZHANG, W., XIE, Z., FANG, T. 2016. An investigation into the effects of silver nanoparticles on natural microbial communities in two freshwater sediments. Environ Pollut, 219: 696-704. http://dx.doi.org/10.1016/j. envpol.2016.06.071

BONHOMME, S., CUER, A., DELORT, A-M., LEMAIRE, J., SANCELME, M., SCOTT, G. 2003. Environmental biodegradation of polyethylene. Polym Degrad Stab, 81: 441452. http://dx.doi.org/10.1016/S0141-3910(03)00129-0

CATTO, A.L., MONTAGNA, L.S., SANTANA, R.M.C. 2017. Abiotic and biotic degradation of post-consumer polypropylene/ ethylene vinyl acetate: wood flour composites exposed to natural weathering. Polym Compos, 38(3): 571-582. http:// dx.doi.10.1002/pc. 23615

CORTI, A., MUNIYASAMY, S., VITALI, M., IMAM, S.H., CHIELLINI, E. 2010. Oxidation and biodegradation of polyethylene films containing pro-oxidant additives: Synergistic effects of sunlight exposure, thermal aging and fungal biodegradation. Polym Degrad Stab, 95: 1106-1114. http:// dx.doi.org/10.1016/j.polymdegradstab.2010.02.018

EPA (Environmental Protection Agency). 1996. Method 3050B: Acid Digestion of Sediments, Sludges, and Soils, Revision 2, Washington, DC.

FONTANELLA, S., BONHOMME, S., BRUSSON, J-M., PITTERI, S., SAMUEL, G., PICHON, G., LACOSTE, J., FROMAGEOT, D., LEMAIRE, J., DELORT, A-M. 2013. Comparison of biodegradability of various polypropylene films containing pro-oxidant additives based on $\mathrm{Mn}, \mathrm{Mn} / \mathrm{Fe}$ or Co. Polym Degrad Stab, 98: 875-884. http://dx.doi.org/10.1016/j. polymdegradstab.2013.01.002

GOLDBERG, D. 1995. A review of the biodegradability and utility of poly(caprolactone). J Environ Polym Degr, 3(2): 61-67. http:// dx.doi.org/10.1007/BF02067481

GONÇALVES, S.P.C., FRANCHETTI, S.M.M. 2015. Biodegradation of PP and PE blended with PHBV in soil samples. Adv Polym Technol, 34(2): 2186. http://dx.doi.10.1002/ adv.21486.

KLEMENČIČ, D., BARBARA SIMONČIČ, B., TOMŠIČ, B., OREL, B. 2010. Biodegradation of silver functionalised cellulose fibres. Carbohydr Polym, 80: 426-435. http://dx.doi.10.1016/j. carbpol.2009.11.049

LUCAS, N., BIENAIME, C., BELLOY, C., QUENEUDEC, M., SILVESTRE, F., NAVA-SAUCEDO, J-E. 2008. Polymer biodegradation: Mechanisms and estimation techniques. Chemosphere, 73: 429-442. http://dx.doi.10.1016/j. chemosphere.2008.06.064

LUGAUSKAS, A., LEVINSKAITÉ, L., PEČIULYTÉ, D. 2003. Micromycetes as deterioration agents of polymeric materials. Int Biodeterior Biodegradation, 52: 233 - 242. http://dx.doi.10.1016/ S0964-8305(03)00110-0

MCGEE, C.F., STOREY, S., ClIPSON, N., DOYLE, E. 2017.
Soil microbial community responses to contamination with silver, aluminium oxide and silicon dioxide nanoparticles. Ecotoxicology, 26: 449-458. http://dx.doi.10.1007/s10646-0171776-5

MONTAGNA, L.S., FORTE M.M.C., SANTANA R.M.C. 2013. Induced degradation of polypropylene with an organic prodegradant additive. J Mater Sci Eng, 3(2): 123-131.

OPREA, S., GRADINARIU, P., JOGA, A., ZORLESCU, B., OPREA, V., POTOLINCA, V.O. 2017. Fungal degradation behavior of two series of polyurethane urea composites obtained by different silver incorporation methods. J Elastomers Plast, 49(2): 120-131. http://dx.doi.10.1177/0095244316639636

PARK, C.H., KANG, Y.K., IM, S.S. 2004. Biodegradability of cellulose fabrics. J Appl Polym Sci, 94: 248-253. http:/ dx.doi.10.1002/app.20879

PITTOL, M., TOMACHESKI, D., SIMÕES, D.N., RIBEIRO, V.F., SANTANA, R.M.C. 2017. Antimicrobial performance of thermoplastic elastomers containing zinc pyrithione and silver nanoparticles. Mat Res, 20(5): 1266-1273. http://dx.doi. org/10.1590/1980-5373-MR-2017-0137

PORTILLO, F., YASHCHUK, O., HERMIDA, E. 2016.Evaluation of the rate of abiotic and biotic degradation of oxo-degradable polyethylene. Polym Test, 53: 58-69. http://dx.doi.org/10.1016/j. polymertesting.2016.04.022

RIBEIRO, V.F., SIMÕES, D.N., PITTOL, M., TOMACHESKI, D., SANTANA, R.M.C. 201). Effect of copper nanoparticles on the properties of SEBS/PP compounds. Polym Test, 63: 204-209. http://dx.doi.org/10.1016/j.polymertesting.2017.07.033

ROÉ-SOSA, A., ESTRADA, M.R., CALDERAS, F., SÁNCHEZARÉVALO, F., MANERO, O., VELASQUEZ, M.T.L.O.D. 2015. Degradation and biodegradation of polyethylene with pro-oxidant additives under compost conditions establishing relationships between physicochemical and rheological parameters. J Appl Polym Sci, 132(43): 42721. http:// dx.doi.10.1002/app.42721

RUSSELL, J.R., HUANG, J., ANAND, P., KUCERA, K., SANDOVAL, A.G., DANTZLER, K.W., HICKMAN, D., JEE, J., KIMOVEC, F.M., KOPPSTEIN, D., MARKS, D.H., MITTERMILLER, P.A., NÚÑEZ, S.J., SANTIAGO, M., TOWNES, M.A., VISHNEVETSKY, M., WILLIAMS, N.E., VARGAS, M.P.N., BOULANGER, L-A., B-A, C., STROBEL, S.A. 2011. Biodegradation of polyester polyurethane by endophytic fungi. Appl Environ Microbiol, 77(17): 6076-6084. http://dx.doi.10.1128/AEM.00521-11

SAMARAJEEWA, A.D., VELICOGNA, J.R., PRINCZ, J.I., SUBASINGHE, R.M., SCROGGINS, R.P., BEAUDETTE, L.A. 2017. Effect of silver nano-particles on soil microbial growth, activity and community diversity in a sandy loam soil. Environ Pollut, 220: 504-513. http://dx.doi.org/10.1016/j. envpol.2016.09.094

SCHLICH, K., HUND-RINKE, K. 2015. Influence of soil properties on the effect of silver nanomaterials on microbial activity in five soils. Environ Pollut, 196: 321-330. http://dx.doi.org/10.1016/j. envpol.2014.10.021

SILLEN, W.M.A., THIJS, S., ABBAMONDI, G.R., JANSSEN, J., WEYENS, N., WHITE, J.C., VANGRONSVELD, J. 2015. Effects of silver nanoparticles on soil microorganisms and maize biomass are linked in the rhizosphere. Soil Biol Biochem, 91: 1422. http://dx.doi.org/10.1016/j.soilbio.2015.08.019

SUSSMAN, E.M., JAYANTI, P., DAIR, B.J., CASEY, B.J. 2015. Assessment of total silver and silver nanoparticle extraction from medical devices. Food Chem Toxicol, 85:10-19. http://dx.doi. org/10.1016/j.fct.2015.08.013

TOMACHESKI, D., PITTOL, M., RIBEIRO, V.F., SANTANA, R.M.C. 2016. Efficiency of silver-based antibacterial additives and its influence in thermoplastic elastomers. J Appl Polym Sci, 133(37). http://dx.doi.10.1002/app.43956 
TOMACHESKI, D., PITTOL, M., LOPES, A.P.M., SIMÕES, D.N., RIBEIRO, V.F., SANTANA, R.M.C. 2017a. Effects of weathering on mechanical, antimicrobial properties and biodegradation process of silver loaded TPE compounds. J Polym Environ, 26(1):73-82. http://dx.doi.10.1007/s10924-0160927-8

TOMACHESKI, D., PITTOL, M., SIMÕES, D.N., RIBEIRO, V.F., SANTANA, R.M.C. 2017b. Effects of silver adsorbed on fumed silica, silver phosphate glass, bentonite organomodified with silver and titanium dioxide in aquatic indicator organisms.
J Environ Sci, 56: 230-239. http://dx.doi.org/10.1016/j. jes.2016.07.018

TOMŠIČ, B., KLEMENČIČ, D., SIMONČIČ, B., OREL, B. 2011. Influence of antimicrobial finishes on the biodeterioration of cotton and cotton/polyester fabrics: Leaching versus biobarrier formation. Polym Degrad Stab, 96:1286-1296. http:// dx.doi.10.1016/j.polymdegradstab.2011.04.004

ZHENG, Y., YANFUL, E.K., BASSI, A.S. 2005. A review of plastic waste biodegradation. Crit Rev Biotechnol, 25: 243-250. http:// doi.org/10.1080/07388550500346359 